UDC: 378.1

DOI: https://doi.org/10.24195/2414-4665-2017-6-19

\author{
Larysa Dunaieva, \\ Doctor of Political Sciences, professor, head of \\ Research institute of Informational and Social Technologies, \\ Odessa National I. I. Mechnikov University, \\ 2, Dvorianska Str., Odessa, Ukraine,
}

Vitalii Zakharchenko,

Doctor of Economics, professor,

Department of Management of International Economic and Innovative Activities, Odessa National Polytechnic University, 1, Shevchenko Avenue, Odessa, Ukraine,

Natalia Zakharchenko, PhD (Candidate of Economic Sciences), associate professor, Department of Economics and Market Relations Modeling, Odessa National I. I. Mechnikov University, 2, Dvorianska Str., Odessa, Ukraine

\title{
WORLD EXPERIENCE IN IMPROVING QUALITY OF EDUCATION: DIRECTIONS, MEANS, NORMS
}

The article deals with the main directions of modernization of the educational system of the European community. Based on the generalization of the experience of improving the quality of education in Western countries, the directions of modernization of education in Ukraine, optimization of higher education and its integration with innovation-oriented production are determined. The purpose of the paper is to justify ways to improve the system of management of the process of modernization of education in Ukraine. The latter is based on the accumulated world experience and is functioning in the context of the realization of the Concept of the implementation of state policy in the sphere of general secondary education reform "New Ukrainian School" for the period up to 2029 and the innovations of the Law of Ukraine "On Higher Education". Higher education financing models, which have been developed in world practice, allow to identify some elements of a new mechanism for education financing in Ukraine. At present, the government and the public are discussing a number of changes to the Law of Ukraine "On Higher Education" and the Tax Code regarding new financial management and the organization of the educational process in general. The reforming of education should be supported by funding. This means that funding should be directly related to the goals, and some incentives should be created to achieve them. The experience of introducing a multi-channel system of financing education with the involvement of non-state sources of funding and expanding the participation of representatives of large and medium-sized businesses in the material support of the system of education, using the system of address financing of students of schools and students of education institutions have shown their effectiveness and are well developed in such countries like Australia, France, Finland, Italy, USA, Japan, Canada. At present, Ukrainian education institutions are gradually stepping up their efforts to enter the world educational space and collaborate with the leading scientific and educational centers of the United States, the European Union. The process of integration of the Ukrainian economy into the world, the entry into the WTO requires taking measures to improve the quality and competitiveness of Ukrainian education in the international educational space, stimulate the growth of exports of educational services by the education system authorities. Successful experience of foreign countries in this area should be taken into account when reforming the national educational system.

Keywords: education, system, space, Bologna process, professionalism, education, school, integration.

\section{Introduction}

The processes of European integration cover more and more spheres of life of the Ukrainian society. With the accession of Ukraine to the European educational space, the most important direction of the modernization of the system of education was the process of improving the management of educational institutions. One of the most important conditions providing the success of the Bologna process is the fact that new qualifications meet the requirements and interests of the labor market [16]. That is why it is expedient to analyze and take into con- sideration the world experience of management of education.

It should be noted that in Bergamo, Norway on May 19, 2005, at the Conference of Ministers of Europe, Ukraine joined the Bologna process, committing itself to make changes to the national education system and to join in defining priorities in the process of creating a united European educational space. Today, 45 European countries, including Ukraine, have signed the Bologna Declaration, which emphasizes the need for European cooperation in ensuring the quality of higher education, improv- 
ing the quality of training specialists, mobility, compatibility of qualifications systems, and strengthening the competitiveness of the European education system.

Many domestic and foreign scholars such as V. Kremen [1], M. Golovko [3], E. Kuznetsov [4], A. Martys [6], I. Sovsun [11], E. Stadny [12], E. Khomeriki [13], L. Shevchenko [14], Y. Shcherben [16], and others were engaged in the implementation of the Bologna process in the educational system. They deal with the issues of coverage of problems of Ukrainian higher education in the context of the Bologna process. However, there is not enough attention paid to the mechanism of improving the system of education in Ukraine in terms of the educational reforms implementation.

The aim of the paper is to justify ways of improving the system of management of the process of modernization of education in Ukraine.

\section{Discussion}

Throughout the period of existence of independent Ukraine, a number of systemic problems have been accumulated in the educational sector of the country, the main ones being the decline of facilities and resources, the aging of teaching staff, low salary, and the reduction of the social status of education workers [1].

Also Ukrainian educational system faces such challenges as inefficient, overly centralized and outdated management and financing system; growing unequal access to quality education; excessive commercialization of educational services; corruption and credentialism; low quality of education and students' level of knowledge and skills; outdated teaching methods, etc.

In order to improve higher education, Ukraine has chosen a European path and in 2005 entered the system of the so-called Bologna process, the essence of which is the formation of a unified European system of higher education. Within the framework of the Bologna Process, a lot of different conferences, workshops were held [3].

Ukraine's integration into the world educational space requires continuous improvement of the national education system, the search for effective ways of improving the quality of educational services, approbation and introduction of innovative pedagogical systems, the real guarantee of equal access of all its citizens to qualitative education, opportunities and freedom to choose education, modernization of the content of education and organization of its adequacy to world trends and requirements of the labor market, ensuring the continuity of education and life-long learning, the development of state-civil management model. That is why Ukraine needs a systemic reform of education, which should be the subject of public consensus, which provides the understanding of the fact that education is one of the main instruments of civilization's progress and economic development.

The modernization of the education system of the European community is currently being carried out in the following main directions:

1) the creation of a common mechanism for obtaining higher professional education, which involves the introduction of a two-level system of training. First degree - obtaining bachelor degree (3-4 years of study) and the second one - master degree (1-2 years);

2 ) enhancement of the quality of higher education by means of the establishment of accredited independent agencies, which are aimed at assessing the quality of the knowledge gained;

3 ) the introduction of the accounting system of the labor-intensive work of study in the conventional national units of labor in all European national systems of education;

4) increasing the mobility of students, which implies the recognition of foreign education documents;

5) ensuring the employment of graduates, which implies an increase in the demand of specialists trained by further education institutions in the territory of all countries in the Bologna process [8].

At present, in all developed countries of the world, strategic directions of reforming the system of further education are defined (Fig. 1)

Strategic directions of reforming the system of further education in Ukraine

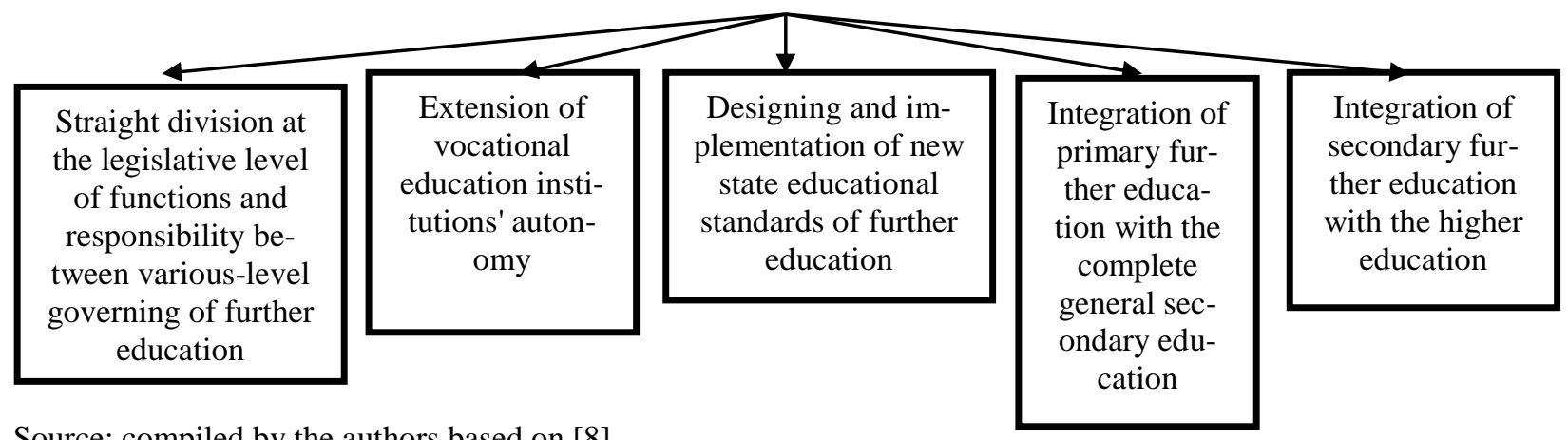

Source: compiled by the authors based on [8].

Fig. 1. - Directions of reforming the system of further education in Ukraine 
These strategic directions were represented in a project Concept of education development for a period 20152025 years suggested by the Ministry of Education and Science of Ukraine and will be accepted after the procedure of public discussion.
This concept involves five basic directions of the development of educational branch reformation which will be realized in the coming years (Table 1).

Basic directions of education reformation in Ukraine

Table 1.

\begin{tabular}{|l|}
\hline \multicolumn{2}{|c|}{ Directions } \\
1. Introduction of a \\
state structure of education \\
according to modern eco- \\
nomical needs and Ukraine's \\
integration into European \\
economic and cultural com- \\
munity.
\end{tabular}

2. Reformation of the education content.

3. Assurance of equal access to quality education for all citizens of Ukraine and education transformation into the mean of social mobility

4. Reformation of the training and retraining system of pedagogical, managerial personnel in educational sector and providing high social standards for workers in educational sphere.

\section{Basic directions of education rent}

- implementation of the typical European standards in terms of basic dura-

tion of schooling (12 years) and academic year;

- transition from one educational level to another should be realized with external independent assessment;

- transition of higher education to the job-specific training;

- transition to the three-year bachelor's degree in higher education.

- implementation of the national curriculum for twelve-year school;

- implementation of union standards / knowledge indicators, skills in the IKT branch for pupils and teachers - equal to the International indexes: PISA in computer skills, industrial international tests Microsoft Certified Educator etc.;

- implementation of a new generation of high education standards based on competence background taking into consideration model standards of "eurobachelor" and "euromaster"

- implementation of encouragement mechanisms for families having difficult socio-economic situation so that their children could obtain pre-school education; adaptation of the system to their needs;

- transformation to the system of ordering books and educational supplies that would be delivered by the government straight to schools; quiting competitive tendering for study materials;

- legalization of family and individual education, simplification and regulation of educational procedures for externship, changing financial principles in small completed schools using vouchers for school education

- implementation of new training programs for administrators in the matters of management and leadership in pedagogical higher establishments;

- implementation of norms, standards, attestation procedures of pedagogical personnel;

- implementation of complex steps for academic staff focused on providing opportunities for their international and domestic academic mobility, creative development and internship (including abroad);

- deregulation of the system of postgraduate pedagogical education, implementation of vouchers for teacher's professional development, providing independent choice of a place for career development;

- legislative support of concluding compulsory written employment agreement with all pedagogical personnel according to independent certification results or performance review, award the staff for implementation progressive training methodologies and technologies, taking into consideration the results of students' EIA and all kinds of work, etc.

- implementation of economic promotion for better educational quality through the government grants system, contract relationships, etc.;

- conducting payment reform of trainers' work: determination of average annual amount of salary for teachers at the level not less than annual GDP per capita

5. Reorganization of managerial, financial system and educational management in term of decentralization, deregulation, implementation of institutional, academic, financial autono-
- implementation of a subsidiarity principle according to the central and local educational administrative bodies;

- reorganization of regional management and educational departments into the service centers and involving civil and others authorities to the control functions in the matters of planned development;

- changing financial strategy of educational establishments in terms of the number of students and cost standard per student; 


\begin{tabular}{|l|c|}
\hline \multicolumn{1}{|c|}{ Directions } & \multicolumn{1}{c|}{ Content } \\
\hline $\begin{array}{l}\text { my of educational estab- } \\
\text { lishments }\end{array}$ & $\begin{array}{c}\text { - implementation of school-based management, transferring point of influ- } \\
\text { ence in a process of making decisions into the school level; } \\
\text { - providing international instructors' participation in the educational process } \\
\text { of Ukrainian universities; mastering the latest interactive, individualized, team } \\
\text { and project educational technologies by teachers; } \\
\text { - assignment of the Ukrainian participation in International monitoring re- } \\
\text { searches such as PISA, TIMSS, PEARLS that should be fixed by the law. Creat- } \\
\text { ing assessment establishments and providing appropriate quality of higher educa- } \\
\text { tion with the assistance of the National agency providing the quality of higher } \\
\text { education. } \\
\text { - implementation of a multichannel financial system in professional educa- } \\
\text { tion involving non-governmental financial sources and expanding participation } \\
\text { representatives of small and medium business in the financial support for support- } \\
\text { ing professional education system, using address financial system for school } \\
\text { pupils and students of higher educational establishments }\end{array}$ \\
\hline
\end{tabular}

Source: compiled by the authors based on [2].

At present, the issue of changing the financing strategy of higher educational institutions has become urgent. According to the Ministry of Education and Science of Ukraine, higher education funding should be based on a formula focused on the ranking and effectiveness of academic institutions in general and higher education institutions in particular that should receive the status of nonprofit organizations. Such changes are necessary for a number of reasons. First of all, there is a lack of real financial autonomy of higher educational institutions, a false financing methodology, and also that public expenditures are not always consistent with the quality of educational services. To do this, it is necessary to make a number of changes to the Law "On Higher Education" and the Tax Code.
Let us consider the international practice of improving the quality of higher education.

The system of professional education financing in the USA is considered to be most effective and multilateral. Higher educational institutions are financed from the federal budget, state budgets, local budgets, at the expense of students (tuition fees), private individuals (donations). Thus, institutions of higher professional education in the United States are financed at the expense of the federal budget by $22 \%, 36 \%$ by state budget, and $19 \%$ by paying tuition, which demonstrates the leading role of public state budget institutes. At the expense of the federal budget, about $60 \%$ of the various planning tasks of federal agencies are financed by state universities and colleges (Fig. 2) [5].

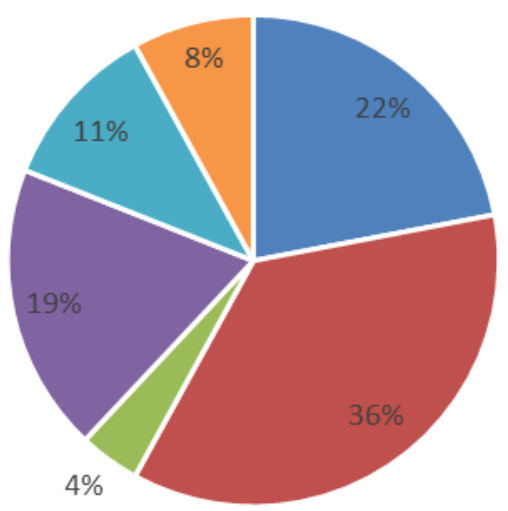

- Federal budget $\|$ State budget $=$ Local budget $=$ Tuition fee $\|$ Commercial activity $=$ Other sources

Source: [14].

Fig. 2. Distribution of Income of Higher Educational Institutions in the United States by sources of funding in 2014

The American system of educational loans includes student loans provided by private lending institutions at very low interest rates and reimbursed by the federal Science and Education, 2017, Issue 6

government, parental and private loans. Students can borrow up to $\$ 2.625$, for the first year, up to $\$ 3.500$ for the second year and up to $\$ 5.500$ every year thereafter. 
More than $6 \%$ of students receive state grants that cover their expenses for education either in part or in whole [6].

It is critical that educators at all levels pay attention to and report on the quality and effectiveness of professional-development activities. Unfortunately, as educators set explanations on the power of professional development to improve teaching, and by extension, student learning, there are few exemplars of professional-learning systems that have been evaluated and been shown to be effective, including those mentioned previously. Some research studies indicate that there are certain features of professional-development programs that contribute to the improvement of teaching and learning, including coaching and mentoring, collaboration among colleagues, observing and discussing classroom practice, and having professional development of duration that teachers have the time to learn and improve [19].

Funding for institutions of higher education in the $\mathrm{UK}$ is provided by universities. Moreover, their composition includes representatives of not only universities, but also large industry. Research works are funded by socalled research councils, which forms a system of dual support. Over the past twenty years, measures have been taken in the UK to reduce public funding for higher education, attracting funds from commercial sources. Particular attention is also paid to the promotion of closer interaction between institutions of higher professional education with the labor market, as well as the increasing role of contractual training in specific areas of training at the expense of attracting funds from interested industrial, commercial and financial organizations. The state actively supports the participation of institutions of higher professional education in the creation of science parks and technology centers, and universities are granted the right to enter the market with research results [11].

China's education management system is currently evolving in two directions: the development of school education in rural areas and the creation of world-class universities. The modern system of higher professional education in China is fee-based, and each student pays about $\$ 600$ USA while studying. Most Chinese families have the opportunity to pay for education at a higher education institution. Individuals in need of assistance receive various subsidies from the government, universities dismiss them partially or completely from education fees and currently in universities of China, about one fifth of all students come from low-income families. The system of support for graduates is widely used, as well as the system of employment of students in the free time. The introduction of educational programs in China has made it possible to increase the availability of higher education. So, if in 1992-2002 they were used by 400 thousand students, then at present - more than 1 million people [13].

The Japanese government annually allocates about $8 \%$ of the state budget expenditure to the education system. At the expense of the state budget the costs of study materials are covered, and half of the budget expenditure is allocated to salary. The rest of the same costs are covered by the budget of the prefectures, which also partly covers the costs of repairing and equipping schools. Up to $60-70 \%$ of the revenue of public universities is provided by the government budget, and the amount of state subsidies depends on the number of students. Currently, as in all other developed countries, in Japan there is a process of transformation of state institutions of higher education into independent administrative corporations, which are aimed at earning an increase in the share of own revenues and maximally efficient use of university budgets. It is noteworthy that there is no financial support for students in Japan, and obtaining higher education degree is paid by the population [12].

Most European countries in 2014, after the crisis in 2009 , increased the volume of public finance support of education, and Ukraine has the largest decline in the real level of spending on education among European countries (Fig. 3).

In Ukraine, the financing of state higher educational institutions is carried out in accordance with Art. 61 of the Law of Ukraine "On Education" No. 1060 dated May, 23, 1991 at the expense of the corresponding budgets, funds of the branches of the national economy, state enterprises and organizations, as well as additional sources of financing [9]. As can be seen in Fig. 2, the requirement to spend $10 \%$ of GDP on the education sector is not fulfilled; on the contrary, funding is reduced. Since 2010, state financing of higher educational institutions has been cut off; they have been financed from revenues for paid tuition as well as the purchase of equipment and books, renovation of dormitories, etc. [18].

Thus, we can present models of higher education financing in world practice (Table 2).

At present, the Government of Ukraine has adopted a draft Law of Ukraine "On Amendments to Some Laws of Ukraine on Higher Education Financing (on Economic Relations in the Field of Higher Education)" and approved the Concept of Implementation of the State Policy in the Reform of General Secondary Education "New Ukrainian School" for the period up to 2029. These issues are subject to broad debate [10].

The main provisions of the proposed model of funding for higher education are laid out in the following elements:

1) basic (block) financing of higher educational establishments;

2) social fund;

3) development fund (capital expenditures fund);

4) the State Targeted Support Fund, where the money will be put in support of those categories of the population for which the state provides additional support for higher education. 


\section{The dynamics of expenditure in most European countries as}

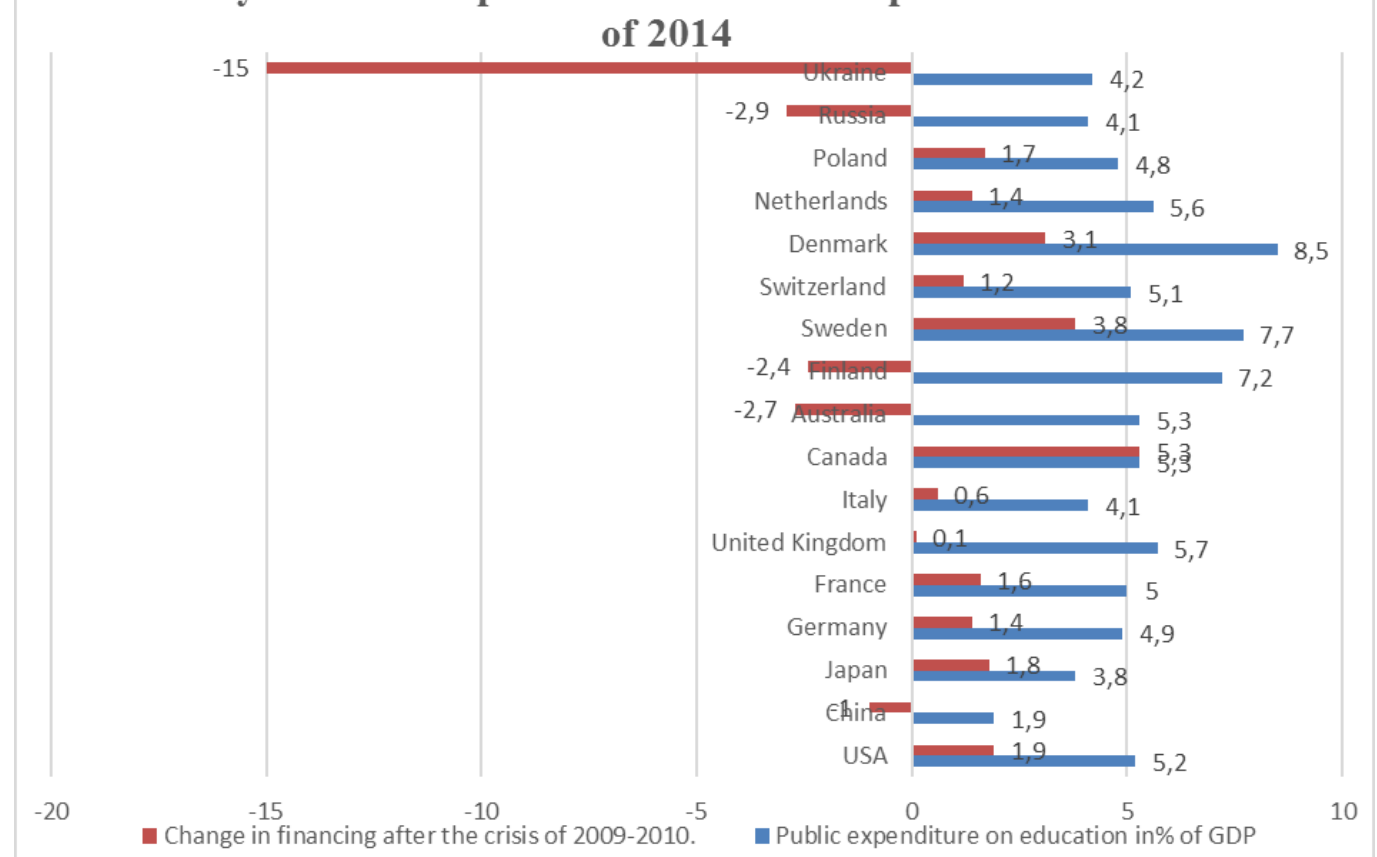

Source: compiled according to [7].

Fig. 3. Dynamics of the cost of financing higher education in Europe, as of 2014

Table 2.

World models of higher education financing

\begin{tabular}{|c|c|c|}
\hline Model & Country & Content \\
\hline $\begin{array}{l}\text { Expenditure } \\
\text { Financing }\end{array}$ & $\begin{array}{l}\text { Canada } \\
\text { United Kingdom } \\
\text { France } \\
\text { Japan } \\
\text { Nigeria } \\
\text { China } \\
\text { Norway } \\
\text { Sweden }\end{array}$ & $\begin{array}{l}\text { It is envisaged that budget funds go directly to higher education institutions, } \\
\text { and their use is clearly controlled by the state. The degree of autonomy, and } \\
\text { hence the responsibility of higher education institutions for providing quality } \\
\text { educational services are low. Budgeting of higher educational establishments } \\
\text { is carried out using three mechanisms: the linear budget - the estimate is dis- } \\
\text { tributed by the type of expenses (salary, equipment, servicing students); pro- } \\
\text { gram budget - distribution of funds by cost centers (by different departments } \\
\text { or, in some cases, even by individual instructors responsible for the program); } \\
\text { finance plan by the type of activity - with the distinction between the cost of } \\
\text { training and research work }\end{array}$ \\
\hline $\begin{array}{l}\text { Financing on the } \\
\text { results }\end{array}$ & $\begin{array}{l}\text { Denmark } \\
\text { USA } \\
\text { Israel } \\
\text { Netherlands } \\
\text { Finland }\end{array}$ & $\begin{array}{l}\text { The allocation of public funds depends on the results of academic and re- } \\
\text { search activities of higher educational institutions - direct (the quality and } \\
\text { volume of provided educational services) and the final (socio-economic effect } \\
\text { of education: career growth of graduates of higher educational institutions, } \\
\text { their income, satisfaction of employers with the quality of graduates training, } \\
\text { etc.). Higher educational institutions have more powers in financial and ad- } \\
\text { ministrative management, but the branch ministry carries out continuous } \\
\text { monitoring of the quality of education }\end{array}$ \\
\hline $\begin{array}{l}\text { Contract finance } \\
\text { education }\end{array}$ & $\begin{array}{l}\text { Italy } \\
\text { Brazil } \\
\text { Argentina } \\
\text { Greece } \\
\text { India }\end{array}$ & $\begin{array}{l}\text { It is based on the results of negotiations between representatives of higher } \\
\text { education institutions and educational ministries or financial institutions. } \\
\text { Formation of the budget of higher educational establishments can occur: a) by } \\
\text { increasing the funds in comparison with the previous period in accordance } \\
\text { with the plans of the educational institution; b) using the "ad hoc" agree- } \\
\text { ments, assuming the political effect of the representatives of this educational } \\
\text { institution in the society; c) the method of establishing a fixed percentage of } \\
\text { national income for each specific institution of higher education. Specialists } \\
\text { do not consider contractual financing of higher education to be effective be- } \\
\text { cause of high economic uncertainty and dependence on external influences. }\end{array}$ \\
\hline
\end{tabular}

Source: compiled by authors based on [14]. 
According to the basic or block financing, a higher educational institution will receive $80 \%$ of guaranteed funding from previous year funds. This will enable the university to plan its work for the next year. The remaining $20 \%$ of funding will be distributed according to the performance indicators of higher educational institutions. Today, these indicators suggest taking into account the number of students who chose a certain university. It is important to pay attention to the financing of a student depending on the chosen specialty. Engineering specialties should receive more funding because they require the use of laboratories and additional equipment. Among other indicators of the university's performance there are scientific publications, research activities, the level of internationalization, graduation rates, and the attraction of other sources of funding for research. The social fund will make it possible to separate funding for university work from scholarships. It is also necessary to divide academic scholarships, according to the results of studying, from social ones. State scholarships in different years allocated $30-40 \%$ of total expenditures for higher education. Today they amount to almost UAH 6 billion. The task of the fourth element of the new model of financing - the development fund (capital expenditures) - is to direct funds to the development projects of the university, or to its capital investment. Private higher education institutions may also receive state funding for students from the best university entrants if they have expressed a desire to study in a private institution [11].

An important element in the management of higher professional education used in such advanced countries as the United States, Great Britain, Canada, Japan, is the integration of professional education in the system of research and development. Integration of higher education and science makes it possible to focus on training highly skilled personnel for all branches of the economy, develop facilities and resources at the appropriate level. The main form of integration of science and education is the carrying out of scientific research by professional educational institutions according to either their own programs and at the request of state and private organizations. In the US and UK, this integration is concentrated in research laboratories, centers and institutions where studies are conducted both with participation and with the control of external organizations. In such research centers undergraduates and doctoral students work on their dissertations. In France, scientific research is carried out in university laboratories, which are units of the National Center for Scientific Research, which provides additional guaranteed funding.

European and American states are paying a lot of attention to improving the quality of higher professional education. It is becoming increasingly important in the process of internationalization of professional education and labor mobility. The largest organization in the field of quality control of further education is the European Network for Quality Assurance in Higher Education, with almost all Member States of the European Union. Associ- ation of European Universities is also a leading organization for monitoring the quality of education, but unlike other organizations for university accreditation, it involves experts from foreign countries. This organization is working closely with American accreditation agencies, which solves the complex task of mutual recognition of accreditation of European and American universities [20].

Almost all developed countries are currently undergoing the process of the education management system decentralizing. In Japan, the central authority for education only creates conditions for the realization of the educational tasks, that is, administrative bodies have no right to control education but only give recommendations. Direct administration of the education system is handled by local authorities. The United States has a similar form of education system management, and currently managing all levels of education is within the competence of states and local governments. US federal education management bodies are dealing with the financing of the education system and the development of national educational standards. France still has a high degree of centralization of education management. However, since 1982, following the adoption of the relevant decision, there is a process of gradual decentralization, which involves the redistribution of management powers in favor of local selfgovernment [15].

Abroad, forms of public participation in the management of the education system are widely used. In Germany, in particular, public participation in the management of education is carried out through various funds. In China, over the past few years, many civil society organizations have been established that are actively involved in the maintenance and development of education. They carry out cooperation between higher educational establishments and secondary specialized educational institutions, which includes conducting educational and research activities [4].

Many structures, routines, programs, initiatives, paradigms, and organizations already exist in the teaching quality arena at large. Research on professional development, for example, notes that the most successful learning efforts are ones that (among other qualities) seek to build on a foundation of what teachers already know [17].

\section{Conclusions}

Having studied the practical world experience of developed countries, it is possible to draw conclusions on the modernization of the system of professional education. It became the most important national project. One of the strenuous directions is equality of access to professional education. In this connection, it is planned to introduce a system of targeted social support for students from low-income families, disabled people, orphans, and to establish an address procedure for paying social scholarships at the expense of state funds for students and institutions of professional education institutions of all levels.

The next direction of professional education modernization is the development of a system of continuous education that meets the needs of the country and the 
trends of the world labor market. In this regard, it is envisaged to create (both at the central and regional levels) a system of forecasting and monitoring of current and future needs of the labor market in the personnel of different specialties and qualifications; to develop the legislative framework for the organization of social partnership of the state, business and further education, which provides for a comprehensive interaction of employers in the innovative development of further education; to stimulate co-

\section{REFERENCES}

1. Kremin, V. (2009). Vyshha osvita Ukrainy i Bolonskyi protses [Higher Education of Ukraine and the Bologna Process]. Ternopil: Navchalna knyha - Bohdan [in Ukrainian].

2. Vyshha osvita $v$ Ukraini [Higher education in Ukraine]. Retrieved from: http://osvita.ua/vnz/ [in Ukrainian].

3. Holovko, M. (2006). Osoblyvosti orhanizatsii ta vdoskonalennia systemy navchannia za umov Bolonskoho protsessu [Features of organization and improvement of the education system in the Bologna process]. Problemy osvity - Problems of education, 43, 7-11 [in Ukrainian].

4. Kuznietsov, E. A. (2015). Profesionalizatsiia upravlinskoi diialnosti: systema, mekhanizm ta innovatsiina dynamika [Professionalization of management activity: system, mechanism and innovation dynamics]. Odesa: Nauka i tekhnika [in Ukrainian].

5. Kurakov, A. L. (2006). Sovershenstvovanie upravleniya professionalnym obrazovaniem: mezhdunarodnyi opyt [Improvement of Management of Further Education: International Experience]. Vestnik $C h G U-B u l l e t i n$ of ChGU, 1, 130-138 [in Russian].

6. Martysh, A. A. (2010). K pyatiletiyu Bolonskogo protsessa v Ukraine [On the Five-Year Plan of the Bologna Process in Ukraine]. Visnyk Prydnipreprovskoi derzhavnoi akademii budivnytstva ta arkhitektury - Bulletin of the Pridniprovie State Academy of Civil Engineering and Architecture, 4-5, 103-111 [in Russian].

7. Mirovoy atlas dannykh: finansirovanie obrazovaniya [World Data Atlas: Financing of Education]. Retrieved from: http://knoema.ru/atlas/topics/ [in Russian].

8. Pro Natsionalnu stratehiiu rozvytku osvity $v$ Ukraini na period do 2021 roku: Prezydent Ukrainy; Ukaz, Stratehia [About the National Strategy for the Development of Education in Ukraine until 2021: the President of Ukraine; Decree, Strategy] (2013). Retrieved from: http://zakon2.rada.gov.ua/laws/show/344/2013. [in Ukrainian].

9. Pro osvitu: Zakon Ukrainy [On Education: Law of Ukraine] (1991). Vidomosti Verkhovnoi Rady URSR Bulletin of the Supreme Council of the Ukrainian SSR, 34, 451. Retrieved from: http://zakon2.rada.gov.ua/laws/show/1060-12 [in Ukrainian].

10. Pro skhvalennia Kontseptsii realizatsi derzhavnoi polityky u sferi reformuvannia zahalnoi ownership and multi-channel financing of further educational institutions, taking into account world experience, as well as developing mechanisms for attracting extrabudgetary funds and creating investment attractiveness of professional education system.

Thus, the development of professional education in Ukraine needs urgent changes, especially in terms of the quality of services provided and financing.

serednoi osvity "Nova ukrainska shkola" na period do 2029 roku : Rozporiadzhennia KMU No 988-r [On the approval of the Concept for the implementation of the state policy in the field of reforming the general secondary education "New Ukrainian School" for the period up to 2029: The CMU Decree No. 988-r] (2016). Retrieved from: $\quad$ http://www.nmc.od.ua/wpcontent/uploads/2017/02/КОНЦЕПЦІЯ.pdf [in Ukrainian].

11. Sovsun, I. (2016). Nova model finansuvannia vyshhoi osvity povynna buty prozoroiu i efektyvnoiu $u$ vykorystanni biudzhetnykh koshtiv [A new model of financing higher education should be transparent and effective in using budget funds]. Retrieved from: http://mon.gov.ua/usi-novivni/novini/2016/03/15/innasovsun-nova-model-finansuvannya-vishhoyi-osviti/] [in Ukrainian].

12. Stadnyi, Ye. (2016). Konceptualna model derzhavnoho finansuvannia $V N Z$ za rezultatamy diialnosti [Conceptual model of state financing of higher educational institutions by results of activity]. Retrieved from: http://www.cedos.org.ua/uk/osvita/kontseptualna-modelderzhavnoho-finansuvannia-vnz-za-rezultatamy-diialnosti [in Ukrainian].

13. Khomeriki, E.A. (2015). Ukrainskoe vysshee obrazovanie $\mathrm{v}$ formate Bolonskogo protsessa: sovremennye tendentsii i problemy [Ukrainian Higher Education in the Bologna Process: Modern Trends and Problems]. Grani-Grani, 7, 6-10 [in Russian].

14. Shevchenko, L.S. (2013). Finansuvannia vyshhoi osvity: dyversyfikatsiia dzherel [Higher Education Financing: Diversification of Sources]. (2013). Teoriia $i$ praktyka pravoznavstva - Theory and practice of jurisprudence, 2 [in Ukrainian].

15. Shyriaieva, L.V. \& Zakharchenko, N.V. (2012). Formuvannia innovatsiinykh pidkhodiv v osvitnii diialnosti [Formation of innovative approaches in educational activities]. Ekonomika: realii chasu. Naukovyi zhurnalEconomy: Realities of Time. Scientific Journal, 3-4 (4-5), 114-123. Retrieved from: http://economics.opu.ua/files/archive/2012/n4-5.html [in Ukrainian].

16. Shcherban, Yu. Yu. (2010). Bolonskii protsess $v$ Ukraine: polozhitelnyy $i$ otritsatelnyy aspekt vnedreniya [Bologna Process in Ukraine: Positive and Negative Aspects of Implementation]. Retrieved from: http://www.rusnauka.com/8_NND_2010/Pedagogica/606 
06.doc.htm [in Russian].

17. Amy M. Hightower and others (2011). Improving Student Learning by Supporting Quality Teaching: A Survey of School Finance: Key Issues, Effective Strategies. $\quad$ Retrieved from: http://www.edweek.org/media/eperc_qualityteaching_12. 11.pdf [in English].

18. High-Quality Professional Development for Teachers Supporting Teacher Training to Improve Student Learning (2007). Retrieved from: https://www.americanprogress.org/wp-

content/uploads/2013/07/DeMonteLearning4Teachers1.pdf [in English].

\section{ЛІТЕРАТУРА}

1. Вища освіта України і Болонський процес: Навч. посібник / За ред. В. Кременя. - Тернопіль: Навчальна книга - Богдан, 2009. - 384 с.

2. Вища освіта в Україні : [Електронний ресурс]. - Режим доступу: http://osvita.ua/vnz/

3. Головко М. Особливості організації та вдосконалення системи навчання за умов Болонського процессу / М. Головко // Проблеми освіти. - 2006. №43. - C.7-11.

4. Кузнєцов Е.А. Професіоналізація управлінської діяльності: система, механізм та інноваційна динаміка : монографія / Е.А. Кузнєцов. - Одеса: Наука і техніка, 2015. - 368 c.

5. Кураков А. Л. Совершенствование управления профессиональным образованием: международный опыт / А. Л. Кураков // Вестник ЧГУ, 2006. - №1. - C.130. -138 .

6. Мартыш А. А. К пятилетию Болонского процесса в Украине / А. А. Мартыш // Вісник Придніпрепровської державної академії будівництва та архітектури, 2010. - №4-5. - С. 103-111.

7. Мировой атлас данных : финансирование образования : [Электронный ресурс]. - Режим доступа: http://knoema.ru/atlas/topics/.

8. Про Національну стратегію розвитку освіти в Україні на період до 2021 року : Президент України; Указ, Стратегія від 25.06.2013 № 344/2013 [Електронний ресурс]. - Режим доступу: http://zakon2.rada.gov.ua/laws/show/344/2013.

9. Про освіту : Закон України від 23.05.1991 p. No 1060 // Відомості Верховної Ради УРСР. - 1991. No 34. - Ст. 451 [Електронний ресурс]. - Режим доступу : http://zakon2.rada.gov.ua/laws/show/1060-12

10. Про схвалення Концепції реалізації державної політики у сфері реформування загальної середньої освіти "Нова українська школа" на період до 2029 року : Розпорядження КМУ о 988-р від 14.12.16 року [Електронний ресурс]. - Режим доступу: http://www.nmc.od.ua/wp-

content/uploads/2017/02/КОНЦЕПЦІЯ.pdf

11. Совсун I. Нова модель фінансування вищої освіти повинна бути прозорою й ефективною у використанні бюджетних коштів : [Електронний ресурс]. -
19. Laura M. Desimone and others (2002). Effects of Professional Development on teachers' Instruction: Results from a three-year Longitudinal Study. Educational Evaluation and Policy Analysis 24 (2), Retrieved from: http://outlier.uchicago.edu/computerscience/OS4CS/lands capestudy/resources/Desimone-Porter-Garet-Yoon-andBirman-2002.pdf [in English].

20. Thomas R. Guskey and Kwang Suk Yoon (2009). What Works in Professional Development? Retrieved from: http://www.k12.wa.us/Compensation/pubdocs/Guskey200 9whatworks.pdf [in English].

Режим доступу: http://mon.gov.ua/usinovivni/novini/2016/03/15/inna-sovsun-nova-modelfinansuvannya-vishhoyi-osviti/

12. Стадний Є. Концептуальна модель державного фінансування ВНЗ за результатами діяльності [Електронний ресурс]. - Режим доступу: http://www.cedos.org.ua/uk/osvita/kontseptualna-modelderzhavnoho-finansuvannia-vnz-za-rezultatamy-diialnosti

13. Хомерики Е. А. Украинское высшее образование в формате Болонского процессе: современные тенденции и проблемы / Е. А. Хомерики // Грані, 2015. - № 7. - С. 6-10.

14. Шевченко Л.С. Фінансування вищої освіти: диверсифікація джерел/Л.С. Шевченко //Теорія і практика правознавства. - 2013. - Вип. 2. - Режим доступу: http://nbuv.gov.ua/UJRN/tipp_2013_2_44

15. Ширясва Л.В. Формування інноваційних підходів в освітній діяльності [Електронний ресурс] / Л.В. Ширяєва, Н.В. Захарченко // Економіка: реалії часу. Науковий журнал. - 2012. - No 3-4 (4-5). - С. 114-123. - Режим доступу: http://economics.opu.ua/files/archive/2012/n4-5.html

16. Щербань Ю.Ю. Болонский процесс в Украине: положительный и отрицательный аспект внедрения [Електронний ресурс] / Ю.Ю. Щербань. - Режим доступу:

http://www.rusnauka.com/8_NND_2010/Pedagogica/606 06.doc.htm

17. Amy M. Hightower and others Improving Student Learning by Supporting Quality Teaching: A Survey of School Finance : Key Issues, Effective Strategies. 2011 // М. Ату [Електронний ресурс]. - Режим доступу:

http://www.edweek.org/media/eperc_qualityteaching_12. 11.pdf

18. High-Quality Professional Development for Teachers Supporting Teacher Training to Improve Student Learning [Електронний ресурс]. - Режим доступу: https://www.americanprogress.org/wpcontent/uploads/2013/07/DeMonteLearning4Teachers1.pdf

19. Laura M. Desimone and others, "Effects of Professional Development on teachers' Instruction: Results 
from a three-year Longitudinal Study / M. Laura Desimone // Educational Evaluation and Policy Analysis 24 (2) (2002). [Електронний ресурс]. - Режим доступу: http://outlier.uchicago.edu/computerscience/OS4CS/lands capestudy/resources/Desimone-Porter-Garet-Yoon-andBirman-2002.pdf
20. Thomas R. Guskey and Kwang Suk Yoon, "What Works in Professional Development?" / R. Thomas [Електронний pecypc]. - Режим доступу: http://www.k12.wa.us/Compensation/pubdocs/Guskey200 9whatworks.pdf

Лариса Миколаївна Дунаєва, доктор політичних наук, професор, директор Навчально-наукового інституту інформаційних та соціальних технологій, Одеський національний університет імені I. I. Мечникова, вул. Дворянська, 2, м. Одеса, Украӥна

Віталій Іванович Захарченко, доктор економічних наук, професор кафедри менеджменту зовнішньоекономічної та інноваційної діяльності, Одеський національний політехнічний університет, пр. Шевченко, 1, м. Одеса, Украйна,

Наталія Вячеславівна Захарченко, кандидат економічних наук, дочент кафедри економіки та моделювання ринкових відносин, Одеський національний університет імені I. I. Мечникова, вул. Дворянська, 2, м. Одеса, Украӥна

\section{СВІТОВИЙ ДОСВІД ВДОСКОНАЛЕННЯ ЯКОСТІ ОСВІТИ: НАПРЯМИ, ЗАСОБИ, НОРМИ}

Метою статті є обгрунтування шляхів удосконалення системи управління процесом модернізації освіти в Україні на основі накопиченого світового досвіду та їі функціонування в умовах упровадження Концепції реалізації державної політики у сфері реформування загальної середньої освіти «Нова українська школа» на період до 2029 року та нововведення Закону України «Про вищу освіту». Моделі фінансування вищої освіти, які склалися у світовій практиці, дозволили визначити елементи нового механізму фінансування освіти в Україні. Наразі ведеться дискусія уряду з громадськістю щодо внесення низки змін до Закону України «Про вищу освіту» та Податкового кодексу щодо нового фінансового менеджменту та організації освітянського процесу взагалі. Стратегія реформування освіти має підтримуватися фінансуванням. Це означає, що фінансування має безпосередньо пов'язуватися 3 цілями, мають бути створені стимули для їх досягнення. Управління, що базується на стимулах і конкуренції, має перевагу перед управлінням за правилами. Досвід упровадження системи багатоканальної системи фінансування освіти із залученням недержавних джерел фінансування і розширення участі представників великого та середнього бізнесу в матеріальній підтримці системи освіти, використання системи адресного фінансування учнів шкіл та студентів закладів освіти показали свою ефективність і досить добре розвинені в таких країнах, як Австралія, Франція, Фінляндія, Італія, США, Японія, Канада. Наразі українські установи освіти поступово активізують свою діяльність із входження в світовий освітній простір і співпраці 3 провідними науковими та освітніми центрами США, Свропейського Союзу. Процес інтеграції української економіки в світовий простір, входження до ВТО вимагають від органів управління системою освіти реалізації заходів щодо підвищення якості і конкурентоспроможності української освіти в міжнародному освітньому просторі, стимулювання зростання експорту освітніх послуг. Успішний досвід зарубіжних держав у цій галузі повинен бути врахований під час реформування національної освітньої системи.

Ключові слова: освіта, система, простір, Болонський процес, професіоналізм, навчання, школа, інтеграція.

Submitted on June, 2, 2017 